\title{
BESSARION ON ECONOMICS AND GEOPOLITICS ${ }^{1}$
}

\author{
Christos P. Baloglou \\ Hellenic Telecommunications Organization, Amaroussion Attikis, Hellas/Greece
}

\begin{abstract}
This paper deals with those aspects of Byzantine intellectual heritage, which belong to the Bessarion's thought and writing. Bessarion, Cardinal of the Roman-Catholic Church, proposed specific, systematic and analytical measures for a re-organization and recovery of the Despotate of Mistra, while, as it is known, he lived there from the end of 1431 until the end of 1436. Then Bessarion, in his capacity as cardinal, showed his continual and undiminished interest to the advancement of Greek nation, as proven by three famous memoranda of scholar. These are appeals to Constantine Palaiologos, Despot of Mistra, as well as to the doge of Venice. Dated July 13, 1453 the letter to the doge informed him on the Fall of Constantinople and the sufferings of Greek nation! Especially noteworthy is the third (and only surviving) letter of Bessarion, addressed to his friend, Despot Constantine Palaiologos in the spring of 1444 . Here Bessarion proposes a specific, specialized program for the economic restructure, social reorganization and military strengthening of the Despotate. The intellectual associates education with economy. Sharing the economic philosophy of ancient Greeks on self-sufficiency and utilization of local means, Bessarion became a forerunner of mercantilism, while also acknowledging the productive contribution of education. The proposal of Bessarion for the transfer of the Despotate's capital closer to the Isthmus was of great geopolitical importance since, when the guarding of the Hexamilion Wall would be reconstructed and constant and properly updated. These proposals, having been so important for the evolution of Byzantine economic thought, took an appropriate place in its development.

Key words: Bessarion, Despotate of Mistra, Palaeologean Renaissance, Byzantine Economic Thought, economics and education, Isthmus of Corinth.

Citation. Baloglou Ch.P. Bessarion on Economics and Geopolitics. Vestnik Volgogradskogo gosudarstvennogo universiteta. Seriya 4. Istoriya. Regionovedenie. Mezhdunarodnye otnosheniya [Science Journal of Volgograd State University. History. Area Studies. International Relations], 2021, vol. 26, no. 6, pp. 171-180. DOI: https://doi.org/10.15688/jvolsu4.2021.6.15
\end{abstract}

УДК 94“04/14”:330.8

Дата поступления статьи: 01.07.2021

ББК 63.3(0)42-2

Дата принятия статьи: 12.10.2021

\section{ВИССАРИОН ОБ ЭКОНОМИКЕ И ГЕОПОЛИТИКЕ ${ }^{1}$}

\author{
Христос П. Балоглу \\ Греческая телекоммуникационная организация, Амаруссион Аттикис, Греция
}

\begin{abstract}
Аннотация. Настоящая статья имеет прямое отношение к тем аспектам византийского интеллектуального наследия, которые неотъемлемо принадлежат творческой мысли и трудам Виссариона. Виссарион, кардинал Римско-католической церкви, предлагал специфичные, систематические и аналитические меры для реорганизации и восстановления Деспотата Мистры в тот период, когда, как известно, он жил там с конца $\vec{ح} 1431$ г. до конца 1436 года. Тогда Виссарион, в его полномочии кардинала, выказал постоянный и неуменьшаОิ ющийся интерес к прогрессу греческой нации, как доказывают три известных меморандума ученого. Они обращены к Константину Палеологу, деспоту Мистры, а также к дожу Венеции. Датированное 13 июля 1453 г. 己் послание дожу информировало его о падении Константинополя и страданиях греческой нации! Особенно б заслуживает внимания третье (и единственно сохранившееся) послание Виссариона, направленное к его другу, деспоту Константину Палеологу, весной 1444 года. Здесь Виссарион предлагает специфичную, специальную программу экономической реконструкции, социальной реорганизации и военного усиления деспо(?) тата. Интеллектуал соединяет образование с экономикой. Разделяя экономическую философию древних гре-
\end{abstract}




\section{ВИЗАНТИЙСКОЕ ОБЩЕСТВО И ГОСУДАРСТВО}

ков о самодостаточности и использовании местных ресурсов, Виссарион становится предвозвестником меркантилизма, одновременно признавая роль образования для производства. Предложение Виссариона о переносе столицы деспотата ближе к Истмийскому (Коринфскому) перешейку обладало великой геополитической значимостью с того времени, когда оборонительная стена Гексамилия была бы восстановлена и постоянно надлежащим образом обновлялась. Эти предложения, столь важные с точки зрения эволюции византийской экономической мысли, заняли надлежащее место в ее развитии.

Ключевые слова: Виссарион, Морейский деспотат (Мистра), Палеологовский Ренессанс, византийская экономическая мысль, экономика и образование, Коринфский перешеек (Истм).

Цитирование. Балоглу Х. П. Виссарион об экономике и геополитике // Вестник Волгоградского государственного университета. Серия 4, История. Регионоведение. Международные отношения. - 2021. - Т. 26, № 6. - С. 171-180. - (На англ. яз.). - DOI: https://doi.org/10.15688/jvolsu4.2021.6.15

Introduction. Bessarion (Trebizond, 2.I.1403 - Ravenna 18.XI.1472) was undoubtedly a distinguished personality that left its mark on its time. He had an excellent education, both secular and ecclesiastical, but distinguished himself mainly as author of philosophical works. Bessarion descended from a pious family with fifteen children of which, however, he was the only one to survive. His secular name was Basileios and he was raised in a manner according to his family's social class. Bessarion studied in his place of birth, for which he later wrote a special encomium. In it Bessarion praised the progressive attitude of the inhabitants and prominent geographical location of Trebizond that contributed to its wealth. Subsequently, Bessarion continued his studies in Constantinople, eventually settling in Mistra, in southern Peloponnese, among the circle of George Gemistos Plethon (Constantinople 1355? - Mistras 24.VI.1452). Being a friend of Constantine Palaiologos (with whom he was approximately the same age), Bessarion joined the circle of scholars active in the period of the emperors Manuel II and John VIII. Byzantine intellectual became a monk under the name Bessarion and reinforced the clergy as deacon and later priest. He was eventually arised to status of Bishop of Nicaea (1437) on the eve of the Council of Ferrara-Florence. Confronted with the crucial issue of his time, that is, how to avert the danger from the East, Bessarion followed the pattern of Demetrios Kydones. He sided with the unionist party and became its unquestionable leader during the Council of Ferrara-Florence (1438-1439). After the return to the Queen of Cities (1440) and the division in the ranks of both clergy and laymen, Bessarion was forced to return to Italy where he was ordained cardinal. His flight and settlement to Italy may be explained by certain facts. Hellenic education continued to be alive in some Italian cities and, mainly, in the Greek monasteries of Apulia and Calabria throughout the Middle Ages. Greeks were a dynamic element of population in the Italian Peninsula, preserving their language, morals and customs. Also, prominent Byzantine scholars, visited Italy, had acquainted with its history. They were fascinated with the history and glory of ancient Rome. It was not by chance that Byzantine scholars tried to associate ancient Rome with the Byzantine Empire. Bessarion's theological works are excessively verbose and full of repetitions. Having a certain aim in mind, Bessarion would often distort the truth. There is no denying of his efforts to unite Christian powers against the imminent Ottoman danger. However, he was confronted with papal tepidity. The indifference towards behalf of rulers was involved in their own conflicting interests and petty ambitions. In conclusion there are insurmountable difficulties in finding the necessary financial means. Bessarion believed that money could be collected by the petition for an antiChristian measure applied by Venice in consequence of behalf of the Pope in 1463. It means the selling of indulgentia, a phenomenon that subsequently became a stepping stone for the Reformation started by Luther and his following.

Since modern economics is generally considered to have begun with the publication of Adam Smith's An Inquiry into the Nature and Causes of the Wealth of Nations in 1776, a survey and investigation of the pre-Smithian economic thought requires some justification. Such an effort must offer both historical and methodological support of its contribution to the study of the history of modern economics.

Most of the histories of economics that give attention to the pre-Smithian background ignore 
the economic thought of Hellenistic and Byzantine Times, as well as Islamic economic ideas, although the Mediterranean crucible was the parent of the Renaissance while Muslim learning in the Spanish universities was a major source of light for non-Mediterranean Europe. Another motivation, and a bit more fundamental, has to do with the "gap" in the evolution of economic thought alleged by J.A. Schumpeter (1883-1950) in his classic, History of Economic Analysis: "The Eastern Empire survived the Western for another thousand years, kept going by the most interesting and most successful bureaucracy the world has ever seen. Many of the men who shaped policies in the offices of the Byzantine emperors were of the intellectual cream of their times. They dealt with a host of legal, monetary, commercial, agrarian and fiscal problems. We cannot help feeling that they must have philosophized about them. If they did, however, the results have been lost. No piece of reasoning that would have to be mentioned hare has been preserved. So far as our subject is concerned we may safely leap over 500 years to the epoch of St. Thomas Aquinas (1225-1274), whose Summa Theologica is in the history of thought what the southwestern spire of the Cathedral of Chartres is in the history of architecture" [46, pp. 73-74]. J.A. Schumpeter classified several pre-Latin European scholastic centuries as "blank", suggesting that nothing in relevance to economics, or for that matter to any other intellectual endeavor, was said or written anywhere else. Such a claim of "discontinuity" is patently untenable. A substantial body of contemporary social thought, including economics, is traceable to Hellenistic, ArabIslamic and Byzantine "giants".

Our purpose in this article is to explore and present the economic philosophy of a distinguished scholar of the post-Byzantine Period, Bessarion of Trapezous (Trebizond 2.1.1403 - Ravenna 18.11.1472) ${ }^{2}$. Following upon this general introduction, the essay deals with the "Great Gap" Thesis (Section 1) and in the subsequent section and sub-sections there will be discussed Bessarion's economic philosophy, his proposals for the social and economic recovery of the Despotate and his proposal in the field of geopolitics. The Conclusions summarize the results of the present research.
The "Great Gap" Thesis. The History of Economic Analysis upon which J.A. Schumpeter worked during the last nine years of his life (1941-1950) [46, p. XL] and which he had not quite finished, makes up a real achievement and is a product of a long preparation and tiring and systematic research. The work is even today impressive in its bibliographic completeness and its detailed range of description. He writes a History of Economic Analysis and not a History of Economic Doctrines or Social and Economic Theories. Despite of this fact he refers to the Ancient Egyptians, Babylonians and Assyrians and to the Chinese political thinkers [46, p. 52]. J.A. Schumpeter recalls the distinction between "Economic Thought" and "Economic Analysis" and emphasizes that the "history of economic analysis begins with the Greeks" [46, p. 52]. He does not refer to the Hellenistic Times and he does not refer to the Hellenistic Times and he does not mention the Byzantine and Islamic ideas. The fact that he does not make any reference to the Byzantine and Islamic economic ideas is the result, as Frank Knight (7.11.188515.4.1972) had assumed, that Schumpeter's History of Economic Analysis was limited to Western economic thinking [27]. This view justifies the fact that J. A. Schumpeter did make a brief reference to the contribution of the Byzantine world. One author identifies him as a pragmatist in his economic philosophy, an "objective scientific investigator with no particular axe to grind" [41, p. 746]. His History of Economic Analysis, edited after his death by his wife and published in 1950, is a monument to his gigantic achievements and it remains the locus classicus of almost all works in this area.

In Chapter two of Part II, J.A. Schumpeter begins with a discussion of the "Great Gap". The implication here is that for over five hundred years prior to the writings to the Scholastics, nothing of any significance to economics particularly said or written anywhere else, as the though the period of Europe's Dark Ages was a universal phenomenon and there was a complete lacuna over intellectual evolution throughout the rest of the world [22; 6, p. 399].

However, the critical question is this: if economic analysis began with the Latin Scholastics, how were they able to develop and assimilate such a voluminous body of thought on 


\section{ВИЗАНТИЙСКОЕ ОБЩЕСТВО И ГОСУДАРСТВО}

economic issues (not to speak of other matters of human intellectual evolution) during the thirteenth, fourteenth and early fifteenth centuries? George O' Brien, writing on medieval economics in the 1920 s, quotes a contemporary French scholar named Jourdain as saying:

"That he carefully examined the work of Alcuin, Rabanas Mauras, Scotus Erigenus, Hincmar, Gerbert, St. Anselm, and Abelard-the greatest lights of theology and philosophy in the early Middle Ages-without finding a single passage to suggest any of these authors suspected that the pursuit of riches, which they despised, occupied a sufficiently large place in national as individual life to offer the philosopher a subject fruitful in reflections and in results" [40, p. 14].

That is, these pre-Aquinas Latin Scholastics had nothing to say on economic matters so they can be eliminated as sources of influence on Thomistic economic thought.

Such "irrelevance" of economics in early Christian thought is clearly acknowledged even by J.A. Schumpeter. Lamenting on this situation, J.A. Schumpeter says: "Whatever our sociological diagnosis of the mundance aspects of early Christianity may be it is clear that the Christian church did not aim at social reform in any sense other than that of moral reform of individual behavior... The How and Why of economic mechanisms were then of no interest either to its leaders or to its writers" [46, p. 72].

However, J.A. Schumpeter argues that the thirteenth century is distinguished from the previous era due to the theological-philosophical revolution, which was caused by the resurrection of "Aristotelian thought". But he dismisses Aristotelian influence as the chief cause of Aquinas's "towering achievement". He insists, "I do not assign to the recovery of Aristotle's writings he role of chief cause of thirteenth century developments. Such developments are never induced by an influence from outside" [46, p. 88].

Now, what was true in J.A. Schumpeter's time, and what has since become even more so is something amply manifested through research in Medieval History. In other words, Scholasticism was ecclesiasticism made up of Patristic, Aristotelian, Neoplatonist, and Arab-Islamic thought. Schumpeter acknowledges all except the last as the major sources of influence. He seems aware of such an influence, as evident from his brief statement and a footnote concerning "Semite mediation" through Avicenna (Ibn Sina, 980-1033), Averroes (Ibn Rushd, 1126-1198) and the Hebrew Maimonides (Ibn Maimon, 1141-1204) [46, p. 87].

Beyond, this, however, Schumpeter chose not to explore. In Bernadelli's words, who, incidentally, points out a similar, but historically minor "mishap" in Schumpeter's History, such an attitude is "all the more disappointing", as Schumpeter "must have been well aware of the fascinating process of cultural diffusion" between the Arab world and the West; and by restricting himself to Europe, J.A. Schumpeter "grossly underestimated the richness in analytical content of the Mesopotamian contributions" [15, p. 320].

Whatever might have been Schumpeter's motivation for disregarding the influence of Byzantine scholars, the results have been most unfortunate for the history of economic thought. Even when one's focus is on the history of Western economic thought, surely the influence of Byzantine contribution is very much part of the western tradition. The fact that this book became a classic, helped to perpetuate the "blind spot" in economics. Any attempt at extracting the economic thought of Thomas Aquinas, as J.A. Schumpeter did, must lead one to consult his Opera Omnia, Summa Theologica, and Summa contra Gentiles, and one cannot do so without seeing some references to Byzantine scholars.

While encounters with Medieval economic thought and Byzantine thought are unavoidable when consulting the works of Latin Scholastics and exploring the writings of early European scholars, invariably such encounters failed to arouse scholarly curiosity on the part of J.A. Schumpeter and others who preceded and succeeded him - especially in reference to medieval economic thought. There is a list of significance textbooks, written by prominent scholars, who are influenced by Schumpeter's "Gap" and who ignore the Byzantine economic thought (for an extensive analysis, see: [6, pp. 402-410]).

The occupation of the Intellectuals and Scholars of the Post-Byzantine Period with economic and social matters. The Byzantine Thought and Literature has not shown a tradition of economic thought, similar to that of the West, and specific contributions which would make up a creative renovation or a systematic elaboration of 
the economic ideas and doctrines of the authors and intellectuals of the Classical Antiquity. From this point of view, a Gap seems to be present in the historical evolution of the economic doctrines and theories, which cannot be covered only by the economic ideas of the Fathers or by the estimation of the Byzantine authors and scholars which are rather rare to find according the nature or the causes of specific economic developments [24, pp. 15-50; 35, pp. 43-73]. Moreover, these ideas are functioning as empirical observations of the economic phenomena or as dutiful suggestions of intervention in the function of the economic process.

From this point of view, it is interesting to explore how the scholars of the Palaiologean period focused to solving the economic and social problems.

The period of the two or three last centuries of the Byzantine Empire, which is directly connected with the name of Palaiologoi, is justified by the fact of the simultaneous appearance of a politically, economically and socially shrunk and weakened state on the one hand and of a significant cultural production which had its influence on and left indelibly its spiritual presence in the Western renaissance on the other hand. This period, known as Post-Byzantine Period or the "Last Byzantine Renaissance", as St. Runciman (7.VII.1903-1.XI.2000) called it [45], begins from the capture of Constantinople by the Greeks (15.VIII.1261) and ends to the capture of the "Basileusa", as it called by the Ottomans (29.V.1453), and is characterized by several economic and political events ${ }^{3}$.

In strange contrast with the political and economic decline, the intellectual life of Byzantium never shone so brilliantly as in those two sad centuries. It was an age of eager and erudite philosophers, culminating in its later years in the most origin al of all Byzantine thinkers, George Gemistos - Plethon. At no other epoch was Byzantine society so highly educated and so deeply interested in things of the intellect and the spirit [45, pp. 1-2].

Another phenomenon of this period, which we have to mention, is the influence on the West. In those two centuries the connection with the Latin West grew closer: not only did Byzantine art influence the early painters of Italy, but Byzantine scholarship also began to move to the West and kindle the fire of the Italian Renaissance $\left[14\right.$, p. 49]. From the $14^{\text {th }}$ century onward the Byzantine scholars were carrying their books and their scholarship to Italy. An example of this influence was the establishment of the Platonic Academy of Florence by Cosimo de Medici, who was inspired by Plethon, who visited Italy and was honored there ${ }^{4}$. Without the Greek educator and diplomat Manuel Chrysoloras coming to teach Greek in Florence in 1397, the history of the Renaissance would have been very different. Without Chrysoloras, Florence would not have claimed the unequivocal leadership in humanist studies at the start of the $15^{\text {th }}$ century as in fact she did. Several generations later, the arrival of John Argyropoulos at the University of Florence, in 1457, restored Florentine leadership in Greek studies and prepared the way for the Platonic Academy [38]. An additional element that characterized the scholars of the period under discussion was the return to the classical patterns, especially to Ancient Sparta and Ancient Athens; they derived their arguments from Classical Greece for a provision of their ideas [43, pp. 130138]. They often used the term Hellene to describe themselves. The use of this term was not an originality of this period, but from the $14^{\text {th }}$ century onward, a general use of this term was observed [18, pp. 273-299].

The intellectuals and scholars of these two centuries did know the problems of the State and tried to provide consistent and systematic solutions. They were influenced by the Classical Patterns, but also by the texts of the Early Christian Fathers. It is evident by Cabasilas's and Magister's proposals, who do refer to Solon, Plato and the Cappadocians [10; 7, pp. 61-68].

Thomas Magister (1275?-1350/51), Alexios Makrembolites (1310/1312?-1360) ${ }^{5}$ and Constantine the Philosopher of Nicaea ( $12^{\text {th }}$ century) [42] accused the riches and especially they develop the idea for a better division of wealth between the citizens. Magister suggested that extra taxation without a specific reason should not be imposed because it revolted citizens and perpetuated social injustice [52, col. $480 \mathrm{~A}$ ]. For this reason, he pleaded to the Emperor to rearrange the system of tax collection and not to sell them [52, col. $480 \mathrm{C}]$. As a consequence of a good and right tax policy there came the correct handling of public money. The Emperor himself should show interest and 


\section{ВИЗАНТИЙСКОЕ ОБЩЕСТВО И ГОСУДАРСТВО}

improve the situation. Under these circumstances the State will be able to get armed regularly and be ready in case of war. "These who practice arts and crafts", wrote Magister, "should be of good repute on other grounds also [as well as on the ground of their skill]". They should not be halfservants of the State: their citizenship should not be limited to the works of peace; "they should also have in their minds a spirit of gallantry and readiness for war" [53, col. $545 \mathrm{D}]$. Magister's main concern was that all alike - the working class of artisans as well as the rich and leisured should have access to a liberal education which would be a training of character as well as of intelligence and would enable all to fulfill "the whole duty of a Christian man" [53, col. 548 B].

Georgios Gemistos - Plethon as a "theoretical philosopher of Neoplatonism" [34, p. 87] and hellenocentric and progressive philosopher [13, pp. 30-31]. His creative doctrine was the main factor of the Neoplatonism in the West [12, p. 104]. Plethon analyzed and delivered specific proposals for the recovery of the Despotate in two treatises. The first one is entitled Advice to the Despot Theodore concerning the Affairs of Peloponnese, presented in 1416 [20; 33, pp. 113-135]. The second treatise is entitled Georgios Gemistos to Manuel Palaeologus concerned the Affairs of the Peloponnes, presented in 1428 [21;32, pp. 246-265]. These treatises belong to a long tradition of the "mirror for princes" $[16$, pp. $30-59 ; 9$, pp. 110 $114 ; 54]$. Both of these treatises or memoranda contain a specific program, which would reform the socioeconomic and military structure of Peloponnese $[44 ; 48]$. The proposals aim at the best confronting of the Ottoman threat, which ultimately was to sweep away the Byzantine Empire in the decade after Plethon's death. The central theme of these reforms is the mobilization of all socio-economic and political factors in order to create a centralized, selfsufficient and defensibly territory.

Plethon considered monarchy to be the best - suited system of government. He claimed that monarchy is the "the safest and most beneficial" [33, p. 199]. For Plethon, the monarch would be surrounded by a council: the number of advisors must certainly be restricted, yet it must be sufficient, the members being of moderate financial status and having an excellent education
[33, pp. 118-199]. However, Plethon was well aware of the various human weaknesses of the statesman and of his civil advisors. Plethon stressed that the selection of civil servants and advisors must be based mainly upon their special knowledge and their non-self-interested behaviour. So, Plethon suggested, that the "best" citizens should be chosen for civil servants by using objective criteria, namely that of meritocracy [33, p. 119]. And their corruption, as T. Nikolaou emphasizes, following to claims of Plethon, must be severely punished (see: [39, pp. 20-52]).

The successful application of the division of labour, which will contribute both to the improvement of the politeia and the achievement of happiness [33, p. 132.7-12], the tripartite division of population [33, pp. 119.23-120.5], the abolishment of the many taxes and the establishment of a unique tax [33, p. 122.18]. Besides, according to Plethon, the reformed tax system must be based upon the four principles of taxation. And by considering agricultural income as the basis of taxation, Plethon proposed the property reform [32, p. 260.1-18], the control of imports and exports [32, pp. 263.3-264.12; 33, p. 264.11-16], constitute the main content of Gemistos's proposals ${ }^{6}$. Thus, Plethon became an ideological predecessor of the main principles of taxation, developed later in the $18^{\text {th }}$ century literature, primarily by Adam Smith (1723-1790) and a forerunner of the relevant Physiocratic theory [48, pp. 122-123; 11, pp. 120-134].

According Plethon's proposals, the agriculture and the security forces (the army) are of paramount importance and interdependent. It is very interesting, this is an idea that imbues Xenophon's Oeconomicus and reappears in Byzantine texts, such as the Taktika of Leo the Wise. Plethon's economic recommendations were based on the presupposition that the Peloponnese, a rich producer of raw materials, could be rendered economically self-sufficient. Plethon argued that the main function of government is the protection of individuals' property rights and peoples' freedom. Thus, it seems that he regarded sovereignty as a kind of "social contract" - a theory more fully explicated during the $17^{\text {th }}$ century by Thomas Hobbes and John Locke [49, p. 691].

Bessarion's place in the Byzantine economic thought. Striding the boundary 
between East and West, Greek and Latin, the Cardinal Bessarion was a major figure in the transmission of Greek learning to the Latin West. Living up 1440, after the end of Ferrara-Florence Council, in Italy, as Cardinal of the Roman-Catholic Church, Bessarion is interested in the problems in the East, and he is looking for the best solutions to save the State.

One of Manuel's sons, Constantine XI (rd. 6.I.1449-29.V.1453), was the last ruler of Byzantium. When he was only the Despot of the Peloponnese, his panegyrists compared him to that other Constantine who had founded the capital of the Empire. From this identity of names the panegyrists drew most favorable inferences as to the future of Constantinople in whose defense Constantine XI was to fall in 1453 (Joh. Dokeianos, Laudatio of Constantine Palaeologus [31, p. 225.4-7]).

In 1444, these future prospects were spelled out in some detail by Constantine's friend Bessarion. It is worth that he sent to Constantine three epistles. These letters prove Bessarion's interest in the themes and problems of the Despotate, but only the third letter has been survived [33, pp. 32-45], and it confirms, that Bessarion was connected with Constantine by friendly relation ${ }^{7}$. Once the Despot had carried out the reforms advocated by Bessarion of the Peloponnese, that is ancient Sparta: the Despot would be able to reconquer the European part of the Empire; next he would cross over to Asia at the head of his regenerated Spartans; thus this new Agesilaus would restore the whole Empire to its ancient greatness [33, p. 36.25-30]. Bessarion expressed the wish that the Greek nation might rule over the whole of mankind [33, p. 44.29-30].

For the achievement of these targets Bessarion proposed a specific reform program:

a. A discretion of the population of the Despotate in taxpayers and soldiers, and in nontax-payers and soldiers [33, p. 35.9-12]. This is the establishment of the division of labour.

b. The reorganization of army [33, p. 36.10-12].

c. The recognition of the bad effects of the wealth and especially of the conspicuous consumption of the inhabitants [33, p. 38.24-30].

d. The control of imports and exports through selective duties. No import duties should be charged on necessary goods, but both the export of goods needed for domestic consumption and the import of luxuries should be hindered by heavy tariffs [33, p. 41.22-29].

e. The culture of the Byzantines, so high in the past, had sunk so low that there were considered ignorant by foreigners. The wisdom and the technological knowhow of the Byzantines had disappeared, but it survived to a great extent among the Latins. In order to raise the level of culture, education and technology in Peloponnese, Constantine should invite Latin specialists there and send a small group of Greek students in Italy [33, p. 42.22-32]. (Cf. [47, p. 177; 55, p. 293]). These half dozen students, as Bessarion specifies four to eight [33, p. 44.7-10], should not be too young, nor should they be too old, for otherwise it would be difficult for them to learn a foreign language. Their program of study should be technological: metallurgy, mechanics, armaments, shipbuilding [33, p. 44.1-4]. The manufacture of that, we would today call consumer goods, might be looked into also, but this was less important [33, p. 44.10-14].

f. The establishment of the capital town of the Despotate in the Isthmus of Corinth. It would better, for geopolitical reasons, the capital town would be in Isthmus.

All of Bessarion's proposals have sounded strange to some members of the Byzantine upper class. When they were young, they had to memorize the elegant periods of Aelius Aristeides and Libanius, not a manual on shipbuilding, in order to qualify for important positions [47, p. 177]. Therefore, Bessarion had to temper his advice. He explained that no loss of face was involved in learning from the Latins. First of all, the Byzantines would only be receiving back what they had given to the West in the Antiquity. Secondly, it was silly to be ashamed for acquiring wisdom. If the Latins had ashamed of receiving culture from the Byzantines long before, they would never have reached the cultural eminence, which they were now enjoying [33, p. 42.29-34].

Bessarion's proposals have been influenced by Georgios Gemistos's program and by the ancient Greek tradition, especially the Spartan legacy. Bessarion's program had more a practical spirit, than the proposals delivered by Gemistos. It is also to worth noting, that Bessarion connected the technical education with the economic 
improvement. He recognized the economic significance of education, and in a matter of fact, he could be seen as a forerunner of the economics of education.

Some of Bessarion's proposals seem to have a great relation and similarity to the corresponding of the mercantilists, like the improvement of the technical education and the improvement of manufacture. Bessarion lived in Italy, when he wrote the letter: it is probably in April 1444, before the battle of Varna (10.XI.1444). And Bessarion did know all the improvements and the technical progress of the Italian cities during the Renaissance. He urged that his reforms be adopted, if the Byzantines were to escape final ruin [33, p. 38.23].

Conclusions. It is obvious that Byzantium had many and difficult problems, both economic and social, financial and religious, existed in the last two centuries of Byzantine history. The scholars did know these serious problems and provided consistent and systematic solutions for the economic recovery of the State.

The scholars of the Despotate of Mistra, especially Gemistos and Bessarion, provided a radical program for recovery. A feature of their programs and analytical proposals is the effective intervention of the State, and especially the Despot. The successful application of the proposed measures depends on his intervention.

Bessarion recognizes the geopolitical significance of Peloponnese for the recovery of the State. And the proposal of scholar to establish the capital in Isthmus, near Corinth, leads to a new perspective. The relation between technical education and economic progress is quite original. This contribution of Bessarion gives him an appropriate place in the evolution of Byzantine economic thought as well as in the history of economic ideas.

\section{NOTES}

${ }^{1}$ The scientific editing of the article is realized by Yury Vin.

${ }^{2}$ For the standard scholarly biographies mention $[56 ; 37 ; 30$, pp. 686-696]. For the Bessarion's life of up to 1458, the work is superior [36, pp. 11-215]. For recent biographies, see: $[17 ; 8]$. For a reexamination of Bessarion's birthdate, see: [26, pp. 641658]. For a brief outline of his life [57, pp. 1-19].
${ }^{3}$ For an extensive analysis, see: [3, pp. 406-413] and the mentioned there literature.

${ }^{4}$ For the causes and consequences of this cultural phenomenon, see: [23; 28, pp. 50-68, 225-226, 252-257; 29, pp. 101-114, 270; 19, pp. 315-372]. For the existence of the phenomenon see the standard work, composed by I. Medvedev [1].

${ }^{5}$ For the economic thought and analysis on economic matters of Alexios Makrembolites the basic reference work is remained the article of I. Sevčenko [47] and dissertation, written by C. Polatof [44].

${ }^{6}$ For an evaluation of Gemistos's economic ideas and their evolution in the history of economic thought, see: [50, pp. 393-416; 51, pp. 279-297; 48; 5; 4, pp. 12$19 ; 25 ; 2]$.

${ }^{7}$ As we conclude from the beginning of the Bessarion's third letter to the Despot Constantine; cf. [33, p. 32.1].

\section{REFERENCES}

1. Medvedev I.P. Vizantiyskiy gumanizm XIV$X V v v$. [The Byzantine Humanism $14^{\text {th }}-15^{\text {th }}$ Centuries]. Saint Petersburg, Aletheia Publ., 1997.341 p. (in Russian).

2. Medvedev I.P. Politicheskaya economiya Georgiya Gemista Plifona [The Political Economy of George Gemistos Plethon]. Vizantiiskii vremennik [Byzantina Chronika], 1973, vol. 34, pp. 88-96. (in Russian).

3. Baloglou C.P. Economic Thought in the Last Byzantine Period. Lowry S T., Gordon B., eds. Ancient and Medieval Economic Ideas and Concepts of Social Justice. Leiden; New York; Köln, Brill, 1998, pp. 405-438.

4. Baloglou C.P. The Economic Thought of Ibn Khaldoun and Georgios Gemistos Plethon. Some Comparative Parallels and Skills. Medioevo Greco, 2002, vol. 2, pp. 1-20.

5. Schefold B., ed. Baloglou C.P. Georgios Gemistos-Plethon: ökonomisches Denken in der spätbyzantinischen Geisteswelt. Athens, Historical Publications St. D. Basilopoulos, 1998. 155 p.

6. Baloglou C.P. History of Economic Thought. The Schumpeterian "Great Gap", the "Lost" Byzantine Legacy, and the Literature Gap. Liacopoulos G., ed. Church and Society: Orthodox Christian Perspectives, Past Experiences, and Modern Challenges. Studies in Honor of Rev. Dr. Demetrios J. Constantelos. Boston, Mass., Somerset Hall Press, 2007, pp. 395-428.

7. Baloglou C.P. Thomas Magistros' Vorchläge zur Wirtschafts- und Sozialpolitik. Byzantinoslavica, 1999, vol. 40, pp. 60-70.

8. Baloglou C.P. Bēssariōnos erga kai èmeres [The Bessarion's Works and Days]. Thessaloniki, Ant. Stamoulis Publ., 2017. 190 p. 
9. Baloglou C.P. Geōrgiou Gemistou Plēthōnos Peri tōn peloponnēsiakōn pragmatōn [Georgios Gemistos Plethon on the Peloponnesian Affairs]. Athens, Eleutherē Skepsis Publ., 2002. 295 p.

10. Baloglou C.P. Ē oikonomikē skepsē tou Nikolaou Kabasila [Nicholas Cabasilas Economic Thought]. Byzantiaka, 1996, vol. 16, pp. 191-214.

11. Baloglou C.P. Plēthōneia oikonomika meletēmata [Plethonic Economic Studies]. Athens, Eleutherē Skepsis Publ., 2001. 215 p.

12. Bargeliotes L. $\overline{\mathrm{E}}$ antiparathesis neōterikēs epistēmēs kai suntērētismou ston Boreio Ellēnismo [The Juxtaposing of Innovative Science and Conservatism in Northern Hellenism]. Parnassos, 1993, vol. 35, pp. 101-126.

13. Bargeliotes L. O ellēnokentrismos kai oi koinōnikopolitikes idees tou Plēthonos [The Hellenocentricism and Plethon's Sociopolitical Ideas]. Athens, s.n., 1989.96 p.

14. Barker E. Social and Political Thought in Byzantium. From Justinian I to the Last Palaeologus. Passages from Byzantine Writers and Documents. Oxford, At the Clarendon Press, 1957. XVI, 239 p.

15. Bernadelli $\mathrm{H}$. The Origins of Modern Economic Theory. Economic Record, 1961, vol. 37, pp. 320-328.

16. Blum W. Byzantinische Fürstenspiegel. Agapetos, Theophylakt von Ochrid, Thomas Magister. Stuttgart, A. Hiersemann, 1981. V, 205 p.

17. Coluccia G. L. Basilio Bessarione: lo spirito Greco e l'Occidente, Firenze, Leo S. Olschki, 2009. VII, $443 \mathrm{p}$.

18. Dieten L., van. Barbaroi, Ellenes und Romaioi bei den letzten byzantinischen Geschichtsschreibern, Actes du XIIe Congres international d'études byzantines. Belgrade, SANU, 1964, vol. I, pp. 273-299.

19. Fouyas, M. Ellēnes kai Latinoi. É ekklēsiastikē antiparathesis Ellēnōn kai Latinōn apo tēs epochēs tou Megalou Phōtiou mechri tēs Sunodou tēs Flōrentias [The Ecclesiastical Diversification of the Greeks and the Latins from the Time of St. Photius to the Council of Florence 858-1439]. The $2^{\text {nd }}$ ed. Athens, Apostolike Diakonia Publ., 1996. 506 p.

20. Georgios Gemistos Plethon. De rebus Peloponnesiacis. Oratio I [To the Despot Theodore Concerning the Affairs of Peloponnese]. Migne J.-P., ed. Gennadii, Constantinopolitani patriarchae, qui et Georgius Scholarius, opera omnia. Parisiis, Apud J.-P. Migne ed., 1860, cols. 841-866. (Patrologiae cursus completus. Series graeca; vol. 160).

21. Georgios Gemistos Plethon. De rebus Peloponnesiacis. Oratio II [To Manuel Palaeologus concerned the Affairs of the Peloponnes]. Migne J.-P., ed. Gennadii, Constantinopolitani patriarchae, qui et Georgius Scholarius, opera omnia. Parisiis, Apud J.-P. Migne ed., 1860, cols. 821-840. (Patrologiae cursus completus. Series graeca; vol. 160).
22. Todd Lowry S., ed. Ghazanfar S. Medieval Islamic Economic Thought. Filling the "Great Gap" in European Economics. London and New York, Routledge, 2003. XVI, $284 \mathrm{p}$.

23. Gill J. The Council of Florence. Cambridge, At the University Press, 1959. XVIII, 454 p., 2 pl.

24. Gotsis G. Problēmata oikonomikēs kai politikēs èthikēs stēn paterikē kai byzantinē skepsē [The Problems of Economic and Political Ethics in the Byzantine-Patristic Thought]. Athens, Sakkoulas Publ., $1997.164 \mathrm{p}$.

25. Karayiannis A. Georgios Plethon-Gemistos on Economic Policy. Benakis L., Baloglou C., eds. Proceedings of the International Conference: Plethon and His Time (Mystras, 26-29 June 2002). Athens; Mystras, Society of Byzantine and Plethonic Studies, 2003, pp. 305-310.

26. Kennedy S. Bessarion's Date of Birth: a New Assessment of the Evidence. Byzantinische Zeitschrift, 2018, vol. 111, pp. 641-658.

27. Knight F. Schumpeter's History of Economics. Southern Journal of Economics, 1954, vol. 21, pp. 261-272.

28. Schweyen-Ott R., ed. Kristeller P.O. Humanismus und Renaissance. Vol. 1. Die antiken und mittelalterlichen Quellen. München, W. Fink Verl., $1974.259 \mathrm{p}$.

29. Schweyen-Ott R., ed. Kristeller P.O. Humanismus und Renaissance. Vol. 2. Philosophie, Bildung und Kunst. München, W. Fink Verl., 1976. 346 p.

30. Labowsky L. Bessarione. Dizionario Biografico degli Italiani, 1967, vol. 9, cols. 686-696.

31. Lampros Sp. Palaiologeia kai Peloponnesiaka. Vol. 1. Athènes, B.N. Grégoriadès, 1972. [69], 358 p.

32. Lampros Sp. Palaiologeia kai Peloponnesiaka. Vol. 3. Athènes, B. N. Grégoriadès, 1972. [37], 371 p.

33. Lampros Sp. Palaiologeia kai Peloponnesiaka. Vol. 4. Athènes, B. N. Grégoriadès, 1972. [31],328 p.

34. Masai Fr. Plethon et le platonisme de Mistra. Paris, Les Belles Lettres, 1956. V, 419 p.

35. Merianos G., Gotsis G. Managing Financial Resources in Late Antiquity. Greek Fathers' Views on Hoarding and Saving. London, Palgave-Macmillan, 2017. XII, $257 \mathrm{p}$.

36. Mioni E. Vita del cardinal Bessarione. Miscellanea Marciana. Venezia, Bibliotheca Nazionale Marciana, 1991, vol. 6, pp. 11-219.

37. Mohler L. Kardinal Bessarion als Theologe, Humanist and Staatsmann. Vol. 1: Dastellung. Paderborn, F. Schoningh, 1923. VIII, 432 p.

38. Monfasani J. Greek Renaissance Migrations. Monfasani J. Greeks and Latins in Renaissance Italy. Studies on Humanism and Philosophy in the $15^{\text {th }}$ Century. Aldershot, Ashgate Variorum, 2004, pp. 1-14.

39. Nikolaou T. Ai peri politeias kai dikaiou ideai tou G. Gemostou Plēthōnos [Georgios Gemistos 


\section{ВИЗАНТИЙСКОЕ ОБЩЕСТВО И ГОСУДАРСТВО}

Plethon's Ideas on State and Justice]. The $2^{\text {nd }}$ ed. Thessaloniki, Centre of Byzantine Studies, 1989. 153 p.

40. O'Brien G. An Essay on Medieval Economic Teaching. London, Longmans, Green \& Co, 1920. VIII, $242 \mathrm{p}$.

41. Newman P., Gayer A., Spencer M., eds. Source Readings in Economic Thought. New York, Norton, 1954. XII, 762 p.

42. Panayotou A. Anekdotos logos Kōnstantinou tou Philosophou [The Inedited Speech of Constantine the Philosopher]. Athena, 2006, vol. 83,pp. 75-82.

43. Pantazopoulos H. Rōmaïkon dikaion, en dialektikē synartēsei pros to Ellēnikon [Roman Law, in Dialectical Function to the Greek Law]. Vol. 3. Thessaloniki, Sakkoulas Publ., 1979. 450 p.

44. PolatofC. Aleksios Makrembolitēs. O bios kai to ergon [Alexios Makrembolites. The Life and Work]. The augm. ed. Thessaloniki, Stamoulis, 2009. 244 p.

45. Runciman S. The Last Byzantine Renaissance. Cambridge, Cambridge Univ. Pr., 1970. 112 p.

46. SchumpeterE.B., Perlman M., eds. Schumpeter J.A. History of Economic Analysis. Repr. ed. London, Routledge, 1994. XLVIII, $1260 \mathrm{p}$.

47. Sevčenko I. The Decline of Byzantium Seen through the Eyes of Its Intellectuals. Dumbarton Oaks Papers, 1961, vol. 15, pp. 167-186.

48. Woodhouse C.M., ed. Spentzas S. Ai oikonomikai kai dèmosionomikai: apopseis tou Geōrgiou Gemistou-Plēthōnos [The Economic and Financial Conceptions of Georgios Gemistos Plethon]. Athens, Kardamitsa Publ., 1996. 190 p.

49. Spiegel H. The Growth of Economic Thought, The $3^{\text {rd }}$ ed. Durham, N. C., Duke Univ. Pr., 1991.901 p.

50. Stephanidis D. O G. Gemistos - Plēthōn kai ē thesis tou en tē Koinōnikē Oikonomikē [G. Gemistos-
Plethon and His Place in the Evolution of Social Economics]. Epithēorēsis koinōnikēs and dēmosias oikonomikēs [Revue des sciences économiques et financières], 1940, vol. 9, pp. 393-416.

51. Stephanidis D. $\bar{E}$ koinōnike oikonomikē en tē istorikē tēs ekseliksei [The Social Economy in Its Historical Evolution]. Vol. I. Athens, Eleutherē Skepsis Publ., 1948. 372 p.

52. Thomas Magister. Peri basileias [On the Empire]. Migne J.-P., ed. Nicephori Callisti Xanthopuli Ecclesiasticae historiae libri XVIII. Parisiis, Apud J.-P. Migne ed., 1865, cols. 447-496. (Patrologiae cursus completus. Series graeca; vol. 145).

53. Thomas Magister. Peri politeias [On the State]. Nicephori Callisti Xanthopuli Ecclesiasticae historiae libri XVIII. Parisiis, Apud J.-P. Migne ed., 1865, cols. 495-548. (Patrologiae cursus completus. Series graeca; vol. 145).

54. Triantare-Mara S. Oi politikes antilēpseis tōn Byzantinōn dianoētōn apo ton 10on ē̄s ton 13 on m.Ch. aiōna [The Political Ideas of the Byzantine Scholars from the $10^{\text {th }}$ to the $13^{\text {th }}$ Century]. Thessaloniki, Erodotos, 2002. 256 p.

55. Vacalopoulos Ap. Istoria tou Neou Ellēnismou [The History of the New Hellenism]. Vol. I. Thessaloniki, s. n., 1974. [16], 481 p.

56. Vast H. Le cardinal Bessarion (1403-1472). Étude sur le chretienne et la renaissance vers le milieu $d u$ XVe siècle. Paris, Hachette, 1878. XV, 472 p.

57. Zorzi M. Cenni sulla vita e la figura del cardinal Bessarione. Fiaccadore G. et al. eds. Bessarione e l'umanesimo: catalogo della mostra. Venezia, Biblioteca Marciana, 27 aprile-31 maggio, 1994. Napli, Vivarium, 1994, pp. 1-19.

\section{Information About the Author}

Christos P. Baloglou, Ph.D., University of Frankfurt am Main, Economist, Hellenic Telecommunications Organization, Chomatianou, 30, 15123 Amaroussion Attikis, Hellas/Greece, chrisbaloglou62@gmail.com, https://orcid.org/0000-0002-2640-5896

\section{Информация об авторе}

Христос П. Балоглу, доктор философских наук Университета Франкфурта-на-Майне, экономист, Греческая телекоммуникационная организация, Хоматиану, 30, 15123 Амаруссион Аттикис, Греция, chrisbaloglou62@gmail.com, https://orcid.org/0000-0002-2640-5896 